\title{
COVID-19 and anxiety in ophtalmologists
}

\section{COVID-19 y ansiedad en oftalmólogos}

José R. Mier-Bolio ${ }^{*}$, José M. Arroyo-González¹, Elizabeth Baques-Guillén ${ }^{1}$, José F. Valdez-Lopez¹, Álvaro J. Torre-García ${ }^{2}$, Olivia E. Rodríguez-Rodríguez ${ }^{3}$ and Gerardo Rivera-Arroyo ${ }^{1}$

${ }^{\top}$ Retina and Vitreous Service, Central Military Hospital; '2Service of Interventional Cardiology, National Institute of Cardiology Ignacio Chávez; ${ }^{3}$ Cardiology Service, Military Graduate School of Health, University of the Army and Air Force. Mexico City, Mexico

\begin{abstract}
Objective: To determine the prevalence of anxiety in ophthalmologists during the COVID-19 (coronavirus disease 2019) pandemic, exposed to severe acute respiratory syndrome by coronavirus type 2 (SARS-CoV-2) working in respiratory triage and outpatient ophthalmology consultation at the Hospital Central Militar in Mexico City. Material and methods: Observational, cross-sectional, descriptive and prospective study, in which a descriptive survey was applied via internet evaluating two anxiety scales (Hamilton scale and generalized anxiety disorder [GAD-7) scale). Results: Thirty-one subjects responded, 17 $(54.84 \%)$ female and 14 (45.16\%) male. Minimum age was 25 years and maximum age was 49 years, with an average age of 34.5 years. The survey consisted of 24 questions, of which 21 were obtained from both anxiety scales (Hamilton + GAD-7) and the remaining three were of epidemiological interest. By rating both scales separately, we observed an average score of 5.16 for the GAD-7 scale and of 8.45 for the Hamilton scale, reflecting a minimal group anxiety. Using the GAD-7 scale, we observed an anxiety prevalence of 48\% (15 physicians). Of the diagnosed cases, 9 (60\%) met a score listed as mild anxiety, 5 (53\%) as moderate and 1 (7\%) as severe. On the Hamilton scale, the prevalence was of $83 \%$ (26 physicians). Of the diagnosed cases, 23 (88\%) had minimal anxiety, 2 (8\%) had minimal-moderate anxiety and 1 (4\%) had severe anxiety. Conclusion: The prevalence of anxiety in ophthalmologists, using the GAD-7 and Hamilton scales was of $48 \%$ and $83 \%$, respectively, and most cases were of mild intensity.
\end{abstract}

Key words: Anxiety. Ophthalmologists. COVID-19. SARS-CoV-2. Pandemic.

\section{Resumen}

Objetivo: Determinar la prevalencia de ansiedad en oftalmólogos durante la pandemia COVID-19 (enfermedad por coronavirus 2019), expuestos al síndrome respiratorio agudo severo por coronavirus tipo 2 (SARS-CoV-2) laborando en el triaje respiratorio y en la consulta externa de oftalmología en el Hospital Central Militar de la Ciudad de México. Material y métodos: Estudio observacional, transversal, descriptivo y prospectivo, en el cual se aplicó una encuesta descriptiva vía Internet en la que se valoraron dos escalas de ansiedad (escala de Hamilton y escala del trastorno de ansiedad generalizada [GAD-7). Resultados: Se estudiaron 31 personas, 17 (54.84\%) mujeres y 14 (45.16\%) hombres. La edad mínima fue de 25 años, la máxima, de 49 años y el promedio, de 34.5 años. La encuesta estaba compuesta por 24 preguntas, de las cuales, 21 se obtuvieron al unir las escalas de ansiedad (Hamilton + GAD-7), las tres restantes de interés epidemiológico.

Correspondence:

*José R. Mier-Bolio

Periférico Blvrd Manuel Ávila Camacho, s/n

Del. Miguel Hidalgo

Date of reception: 13-06-2020

Date of acceptance: 22-07-2020

C.P. 11200 Mexico City, Mexico

E-mail: josemierb@gmail.com

DOI: 10.24875/RMOE.M20000132
Available online: 09-11-2020 Rev Mex Oftalmol (Eng). 2020;94(6):223-227

www.rmo.com.mx 2604-1731/@ 2020 Sociedad Mexicana de Oftalmología. Published by Permanyer. This is an open access article under the CC BY-NC-ND license (http://creativecommons.org/licenses/by-nc-nd/4.0/). 
Rev Mex Oftalmol (Eng). 2020;94(6)

Al valorar ambas escalas por separado, obtuvimos una puntuación promedio de 5.16 para la escala GAD-7 y de 8.45 para la de Hamilton, lo que refleja una ansiedad mínima grupal. Usando la escala GAD-7 se observó una prevalencia de ansiedad del 48\% (15 médicos). De los casos diagnosticados, 9 (60\%) cumplieron un puntaje catalogado como ansiedad leve, 5 (53\%), como moderada y $1(7 \%)$, como severa. Con la escala de Hamilton, la prevalencia fue del 83\% (26 médicos). De los casos diagnosticados, 23 (88\%) con ansiedad mínima, 2 (8\%) con ansiedad mínima-moderada y 1 (4\%) con ansiedad severa. Conclusion: La prevalencia de ansiedad en oftalmólogos, usando la escala GAD-7 y la escala de Hamilton, fue del 48 y $83 \%$, respectivamente, la mayoría de intensidad leve.

Palabras clave: Ansiedad. Oftalmólogos. COVID-19. SARS-CoV-2. Pandemia.

\section{Introduction}

The Mexican Clinical Practice Guide on the "Diagnosis and Treatment of Anxiety Disorders in Adults" defines anxiety as an unpleasant emotional state that is accompanied by somatic and mental changes, which can appear as an adaptive reaction or as a symptom or syndrome that accompanies various medical and psychiatric conditions. Anxiety is considered pathological due to its irrational presentation, either because the stimulus is absent, the intensity is excessive in relation to the stimulus, or the duration is unjustifiably long and the recurrence is unmotivated, generating an evident degree of dysfunction in the person'.

The pandemic caused by the outbreak of the new virus, severe acute respiratory syndrome due to coronavirus type 2 (SARS-CoV-2), has been strongly linked with the ophthalmology guild ${ }^{2-3}$ since it began. One of the pioneers in discovering the outbreak was Dr. Li Wenliang, a Chinese ophthalmologist who worked at the Wuhan Central Hospital in Hubei Province, Chi$\mathrm{na}^{2-5}$. Dr. Li Wenliang became infected from an asymptomatic patient diagnosed with acute angle closure glaucoma. On January 10, 2020, Dr. Li manifested symptoms of the new virus and died on February 7 , $2020^{2}$.

In Mexico we do not have all the necessary tools to fight this pandemic. It is well known that there is not enough health personnel, hospital capacity, and supplies, which is why health personnel are one of the populations with the highest risk of developing anxiety disorders. Some of the factors that can trigger anxiety in health personnel are long working hours, the risk of acquiring the infection, not having full protective equipment, loneliness, physical and emotional fatigue, as well as distancing from the loved ones ${ }^{6-9}$.

Multiple scales have been designed to measure the severity of anxiety disorders. Two of the most widely used scales worldwide and previously validated in the Mexican population are the Hamilton scale and the generalized anxiety disorder (GAD-7) scale. Both are based on a series of questions about events that could be triggering anxiety, and, according to the answers, an addition of the items is made; the greater the anxiety the greater the sum of the items $s^{10,11}$.

The purpose of this study is to know the prevalence of anxiety in a group of ophthalmologists working during the COVID-19 pandemic in a tertiary hospital.

\section{Material and methods}

A descriptive survey was carried out, with an observational, cross-sectional, descriptive and prospective methodological design. The primary objective was to determine the prevalence of anxiety in ophthalmologists in charge of patient care during the COVID-19 pandemic.

The study was conducted on ophthalmology personnel from all subspecialties of the Central Military Hospital, in Mexico City, during May 2020. All participants previously signed an informed consent.

Our inclusion criteria were indistinct gender, not having chronic degenerative diseases or psychiatric illness previously diagnosed or under treatment, and being part of the ophthalmology department staff attending patients during the COVID-19 pandemic. This included residents, fellows and staff physicians from the different ophthalmology subspecialties.

A questionnaire was prepared with 24 questions. The survey was applied via the Internet using the SurveyMonkey ${ }^{\circledR}$ platform during May 2020. Anxiety levels were measured using the Hamilton and the GAD-7 anxiety scales, both previously validated in the Mexican population.

The scales are interpreted with an ascending numerical value. The Hamilton scale consists of 14 questions, with values ranging from 0 to 4 ; the severity of anxiety is interpreted with the final result after the sum of the items; minimal anxiety is considered with values less than or equal to 17 , minimal to moderate with values of 18 to 24 , moderate with values of 25 to 30 and severe with a value greater than 30 . 
Table 1. Results by sex of the generalized anxiety disorder (GAD-7) scale

\begin{tabular}{|l|c|c|c|c|}
\hline Sex & Minimum score & Maximum score & Average score & Number of doctors diagnosed with anxiety \\
\hline Female & 0 & 17 & 5.5 & $8(53 \%)$ \\
\hline Male & 0 & 10 & 4.6 & $7(47 \%)$
\end{tabular}

The GAD-7 scale, which assesses the state of anxiety in the last 2 weeks, is made up of 7 questions, with values from 0 to 3 , and likewise, the severity of anxiety is interpreted by the sum of the items, reporting minimal anxiety with values between 5 and 9 , moderate with values between 10 and 14 and severe with a score of 15 or more.

\section{Results}

The entire population completed the survey, in an average time of 3 minutes.

The study included 31 people, 17 (54.84\%) women and $14(45.16 \%)$ men. The minimum age was 25 years, the maximum 49 years, and the average age was of 34.5 years (Appendix 1).

The average age divided by sex was 33.47 years for females and 35.85 for males. The primary variable of interest was to determine anxiety in ophthalmologists working in a tertiary hospital during the COVID-19 pandemic.

We conducted a survey using the SurveyMonkey $\AA$ platform via the Internet, composed entirely of 24 questions, of which 21 were obtained by combining two anxiety scales (Hamilton + GAD-7), where a total of 77 items were obtained. The 3 remaining questions did not influence the sum of the items since they were of epidemiological interest: age, sex and name initials.

Using the GAD-7 scale, a prevalence of anxiety of $48 \%$ (15 people) of the total sample was observed, 9 $(60 \%)$ people met a score classified as mild anxiety, 5 (33\%) people as moderate anxiety and $1(7 \%)$ person as severe anxiety (Fig. 1).

We analyzed the GAD-7 scale in detail, where we obtained a minimum value of 0 , maximum of 17 and an average of 5.16, which reflects a mild anxiety disorder as a group.

The analysis by sex is represented in Table 1 .

Using the Hamilton scale, a prevalence of anxiety of $83 \%$ (26 people) of the total sample was observed, 23 $(88 \%)$ met a score classified as minimal anxiety, $2(8 \%)$ as minimal-moderate and $1(4 \%)$ as severe (Fig. 1).

When conducting a complete analysis of the Hamilton scale, the results were the following: the minimum score

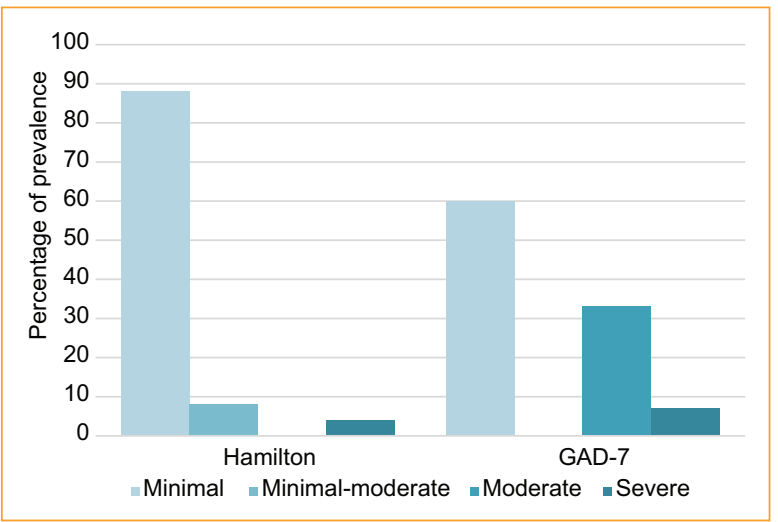

Figure 1. Prevalence and severity of anxiety represented in percentages.

was 0 , the maximum was 43 and the average was 8.45 , which reflects a minimum severity of anxiety as a group. The results divided by sex are presented in Table 2.

\section{Discussion}

This study analyzed, through a descriptive survey, the anxiety levels in ophthalmologists. Two of the most widespread scales worldwide were used, the GAD-7 scale and the Hamilton scale, both previously validated for a Mexican population. The population studied was made up of 31 ophthalmologists, working during the COVID-19 pandemic, exposed to the SARS-CoV-2 in an outpatient clinic for ocular emergencies and assessment of respiratory triage.

A final score was obtained by the GAD-7 scale of 5.16 points and by the Hamilton scale of 8.45 points; both correspond to an anxiety disorder with a mild severity as a group.

Using the GAD-7 scale, a prevalence of anxiety of $48 \%$ (15 doctors) was observed. Of the total sample, 9 (29\%) met a score classified as mild anxiety, 5 (16\%) as moderate and 1 as severe. With the Hamilton scale, the prevalence was of $83 \%$ (26 physicians), 23 people (74\%) with minimal anxiety, 2 with minimal-moderate, and one person with severe anxiety. 
Rev Mex Oftalmol (EnG). 2020;94(6)

Table 2. Results by sex of the Hamilton scale

\begin{tabular}{|l|c|c|c|c|}
\hline Sex & Minimum score & Maximum score & Average score & Number of doctors diagnosed with anxiety \\
\hline Female & 0 & 20 & 7.5 & $13(50 \%)$ \\
\hline Male & 0 & 43 & 9.5 & $13(50 \%)$ \\
\hline
\end{tabular}

In contrast, Cuiyan Wang, et al., in China, through an online survey created for the general population, reported that a third of the 1,210 participants had a generalized anxiety disorder with a severity of moderate to severe ${ }^{7}$.

Ravi Philip Rajkumar, in a systematic review of the relationship between COVID-19 and mental health, reports that, of all the mental health disorders that people may present, anxiety disorder is the most common ${ }^{12}$.

The Mexican Ministry of Health estimates that $70 \%$ of the Mexican population will become infected by COVID-19, which would cause hospital collapse and saturation due to the lack of a health system with the capacity to deal with a pandemic, which is why a level of anxiety is perceived in health personnel ${ }^{4}$.

The anxiety levels generated by the pandemic, specifically in health personnel, will be managed differently by each person. Some of the anxiety-triggering risk factors are age, gender, personnel specialty or training, previous psychiatric illnesses, or personal experiences during the pandemic $\mathrm{c}^{6-8}$.

It is clear that the COVID-19 pandemic has generated a response by psychiatric services and related professionals, in which mental disorders are taken into consideration especially in health personnel, in such a way that it is convenient to know the prevalence of this disease in different risk groups, in order to distribute human resources efficiently ${ }^{12,13}$.

So far this is the first Mexican study to document the prevalence of anxiety in Mexican ophthalmologists working in a tertiary hospital during the COVID-19 pandemic.

\section{Conclusion}

The prevalence of anxiety in ophthalmologists, using the GAD-7 and Hamilton scales, was of $48 \%$ and $83 \%$, respectively; the majority was of mild intensity.

\section{Funding}

The authors received no specific funding for this work.

\section{Conflicts of interest}

The authors declare no conflict of interests.

\section{Ethical disclosures}

Protection of human and animal subjects. The authors declare that no experiments were performed on humans or animals for this study.

Confidentiality of data. The authors declare that they have followed the protocols of their work center on the publication of patient data.

Right to privacy and informed consent. The authors have obtained the written informed consent of the patients or subjects mentioned in the article.

\section{References}

1. CENETEC Trastornos de ansiedad. Guía de Referencia Rápida. Diagnóstico y tratamiento de los trastornos de ansiedad en el adulto. 2010. Disponible en: http://www.cenetec.salud.gob.mx/descargas/gpc/ CatalogoMaestro/392_IMSS_10_Ansiedad/GRR_IMSS_392_10.pdf.

2. Parrish RK II, Stewart MW, Duncan Powers SL. Ophthalmologists Are More Than Eye Doctors-In Memoriam Li Wenliang. Am J Ophthalmol. 2020;213:A1-A2.

3. Wenliang L, Year LN. All eyes on Coronavirus - What do we need to know as ophthalmologists. Indian J Ophthalmol. 2020;68(4):549-53.

4. Emparan JPO, Garza-Leon M, García-Aguirre G, Azcárate-Coral T, Penniecook JA, Lansingh VC, et al. Recomendaciones para el manejo de pacientes que requieren atención oftalmológica durante la pandemia de SARS-CoV-2. Rev Mex Oftalmol. 2020;94(3):103-12.

5. Harapan H, Itoh N, Yufika A, Winardi W, Keam S, Te H, et al. Coronavirus disease 2019 (COVID-19): A literature review. J Infect Public Health. $2020 ; 13: 667-73$.

6. Shanafelt T, Ripp J, Sinai M, Trockel M. Understanding and Addressing Sources of Anxiety Among Health Care Professionals During the COVID-19 Pandemic. JAMA. 2020;323(21):2133-4.

7. Wang C, Pan R, Wan X, Tan Y, Xu L, Ho CS, et al. Immediate psychological responses and associated factors during the initial stage of the 2019 coronavirus disease (COVID-19) epidemic among the general population in China. Int J Environ Res Public Health. 2020;17(5):1729.

8. Tsamakis K, Rizos E, Manolis A, Chaidou S, Kympouropoulos S, Spartalis $\mathrm{E}$, et al. [Comment] COVID-19 pandemic and its impact on mental health of healthcare professionals. Exp Ther Med. 2020;19(6):3451-3.

9. Kang L, Li Y, Hu S, Chen M, Yang C, Yang BX, et al. The mental health of medical workers in Wuhan, China dealing with the 2019 novel coronavirus. The Lancet Psychiatry. 2020;7(3):e14.

10. Ruiz MA, Zamorano E, García-Campayo J, Pardo A, Freire O, Rejas J. Validity of the GAD-7 scale as an outcome measure of disability in patients with generalized anxiety disorders in primary care. J Affect Disord. 2011;128(3):277-86.

11. Maier W, Buller R, Philipp M, Heuser I. The Hamilton Anxiety Scale: reliability, validity and sensitivity to change in anxiety and depressive disorders. J Affect Disord. 1988;14(1):61-8.

12. Rajkumar R. COVID-19 and mental health: A review of the existing literature. Asian J Psychiatr. 2020;52:102066

13. Pappa S, Ntella V, Giannakas T, Giannakoulis V, Papoutsi E, Katsaounou P. Prevalence of depression, anxiety, and insomnia among healthcare workers during the COVID-19 pandemic: A systematic review and meta-analysis. Brain Behav Immun. 2020 May 8. 


\section{Appendix}

Appendix 1. Summary results of the study population.

\begin{tabular}{|c|c|c|c|c|}
\hline Ophthalmologist & Age (years) & $\begin{array}{c}\text { Sex } \\
F=\text { female } \\
M=\text { male }\end{array}$ & GAD-7 & Hamilton \\
\hline 1 & 29 & $\mathrm{M}$ & 3 & 7 \\
\hline 2 & 40 & $\mathrm{M}$ & 0 & 5 \\
\hline 3 & 31 & $\mathrm{~F}$ & 10 & 14 \\
\hline 4 & 48 & $M$ & 7 & 11 \\
\hline 5 & 36 & $M$ & 3 & 8 \\
\hline 6 & 34 & M & 6 & 9 \\
\hline 7 & 32 & $\mathrm{~F}$ & 7 & 3 \\
\hline 8 & 37 & $F$ & 4 & 8 \\
\hline 9 & 32 & $\mathrm{~F}$ & 2 & 7 \\
\hline 10 & 36 & M & 9 & 43 \\
\hline 11 & 42 & $\mathrm{~F}$ & 1 & 2 \\
\hline 12 & 42 & $\mathrm{~F}$ & 0 & 0 \\
\hline 13 & 43 & $F$ & 0 & 0 \\
\hline 14 & 28 & $\mathrm{~F}$ & 4 & 5 \\
\hline 15 & 36 & $F$ & 12 & 20 \\
\hline 16 & 28 & $\mathrm{M}$ & 0 & 1 \\
\hline 17 & 32 & $\mathrm{~F}$ & 1 & 7 \\
\hline 18 & 34 & $F$ & 1 & 0 \\
\hline 19 & 30 & $F$ & 11 & 2 \\
\hline 20 & 40 & $\mathrm{M}$ & 9 & 8 \\
\hline 21 & 25 & $\mathrm{~F}$ & 0 & 0 \\
\hline 22 & 28 & M & 7 & 8 \\
\hline 23 & 29 & $\mathrm{~F}$ & 7 & 9 \\
\hline 24 & 29 & $\mathrm{~F}$ & 6 & 16 \\
\hline 25 & 29 & $\mathrm{M}$ & 2 & 1 \\
\hline 26 & 30 & $\mathrm{M}$ & 0 & 0 \\
\hline 27 & 49 & $M$ & 0 & 1 \\
\hline 28 & 32 & $F$ & 12 & 15 \\
\hline 29 & 30 & $M$ & 9 & 17 \\
\hline 30 & 35 & $\mathrm{~F}$ & 17 & 20 \\
\hline 31 & 45 & $\mathrm{M}$ & 10 & 15 \\
\hline
\end{tabular}

GAD-7: generalized anxiety disorder scale. 